\title{
The role of culture in student discipline of secondary schools in cross- cultural context: A systematic literature review and future research agenda
}

\begin{abstract}
Purpose - The present study is a systematic review that identifies future research avenues on culture and discipline in secondary schools in a cross-cultural context.

Design/methodology/approach - The literature, as published in top management, education, and psychology journals, was reviewed around culture and discipline in secondary schools. This systematic literature review used several PRISMA guidelines and categorised the studies published during the period of 2014 to 2020 .

Findings - The author identified six major themes: 1) Punishment, 2) Restorative practices, 3) Racial disparities, 4) Competitiveness, 5) School Climate, and 6) student discipline in a crosscultural context. Further, the author suggested several future research avenues under these emerging themes.

Research limitations/implications - The scope of this study is limited to culture and discipline in a secondary school context. The findings provide a solid foundation for researchers in the areas of culture and discipline in secondary schools.

Originality/value - To the best of the author's knowledge, this study can be considered as the first systematic literature review conducted using PRISMA guidelines to identify several under-researched areas in the field of culture and discipline in secondary schools in a crosscultural context. The study provides several future research insights.
\end{abstract}

Keywords - Cross cultural context, systematic literature review, secondary schools, discipline Paper type - Literature review

\section{Introduction}

The focus of this paper is to review research papers published on culture and discipline in secondary schools in a cross-cultural context and to identify possible future research avenues. Hue (2001) showed that in some schools many teachers expressed concern that half of all classroom time was spent managing students' behaviour, rather than on instruction. Another reason to conduct this study is that most of the studies on student discipline focused on parenting and education generally point towards a positive correlation with some performance indicators, and very few studies empirically test discipline as a driver of academic performance (Baumann, Winzar, \& Viengkham, 2020). Further, several researchers identified that students 
from different cultural backgrounds has different disciplinary behaviours (Baumann et al., 2020; Jenkins \& Ueno, 2017; Vincent, Sprague, Pavel, Tobin, \& Gau, 2015). Therefore, it is essential to investigate the role of culture and discipline in secondary schools in a cross-cultural context, which is an important area worth further investigation. Moreover, during the literature review, it was identified that none of the studies up to date were found which systematically reviewed literature on the role of culture of student discipline in secondary schools using Preferred Reporting Items for Systematic Reviews and Meta-Analyses (PRISMA) guidelines. Therefore, this study can be considered as the first systematic literature review to identify future research avenues on culture and discipline in secondary schools in a cross-cultural context. Therefore, this leads to the formation of the research question: "What are the future research perspectives on culture and discipline in secondary schools in a cross-cultural context?"

School discipline can be defined as "all activities that are implemented to control learner behaviour to enforce compliance and maintain order" (Bechuke \& Debeila, 2012). Further, Cameron (2006) indicated school discipline as the school policies and actions taken by school personnel to prevent students from engaging in unwanted behaviours. According to Cameron (2006), school discipline has two main goals. The first goal is to ensure the safety of staff and students, and the second goal is to create an environment that encourages learning. Serious student misconduct involving violent or criminal behaviour defeats these goals and often makes headlines in the process (Cameron, 2006). However, the commonest discipline problems involve noncriminal student behaviour. These less dramatic problems may not threaten personal safety, but they still negatively affect the learning environment. Disruptions interrupt lessons for all students, and disruptive students lose even more learning time (Cameron, 2006). Therefore, school administration bodies need to develop various rules and regulations to maintain a peaceful school environment (Lawa, Wiyono, \& Supriyanto, 2019; Mansfield, Fowler, \& Rainbolt, 2018; Nakpodia, 2010).

Moreover, culture can be defined as the ideas, customs, and social behaviours of a particular people in a society (Cobley, 2008). Culture, by its simplest terms, is a system of meaning shared by a group of people to make sense of their reality, or as Hofstede (1991) put it: "the collective programming of the mind" (Baumann et al., 2020; Kuczynski, Marshall, \& Schell, 1997). Culture greatly influences the thinking pattern of a person, as well as how they speak, act, and experience the world around them (Baumann et al., 2020). In eastern and western educational settings, culture plays an important role. For example, many North East Asian parents in Japan 
and China provide additional tutoring to their children for subjects such as maths, science, and language (Yamamoto \& Brinton, 2010). Park and Abelmann (2004) stated that even in the 1990s, private classes on English language were popular in Korea.

Different countries use different methods to handle disciplinary issues in a secondary school context. In America, teachers' conventional approaches to school discipline include suspension, corporal punishment to manage student behaviours and maintain order (Cameron, 2006). A comparison study on Chinese and American cultures found that Chinese parents use stricter disciplinary actions to help their children to achieve educational success (Chao, 1994; Chen, 2005). In developing countries, teachers use more equal or rigid gender roles to maintain higher classroom disciplinary levels (Chiu \& Chow, 2011). In contrast, developed countries have more teacher support and teacher-student relationships to maintain higher classroom disciplinary levels (Chiu \& Chow, 2011)

Several studies assessed the student discipline and academic performance using the data from the Programme for International Student Assessment (PISA), which is a worldwide project by the Organisation for Economic Co-operation and Development (OECD) (Baumann et al., 2020). PISA started in 2000 and is conducted every three years (Baumann \& Hamin, 2011). In the last few testing rounds, Confucian societies (such as China, Japan, Korea, Singapore, Taiwan, and Vietnam) outperform the West and other Asian societies, indeed outperforming the majority of the world (Baumann et al., 2020).

\section{Systematic literature review approach}

Systematic literature reviews (SLR) are often contrasted with traditional literature reviews because systematic reviews are objective, replicable, systematic, and comprehensive, and the process is reported in the same manner as for reporting empirical research (Weed, 2005). The purpose of this systematic literature review was to identify the future research areas on culture and discipline in secondary schools in a cross-cultural context. The author conducted the database search manually using several keywords, such as "culture and discipline in secondary schools", "why discipline and culture matters in secondary schools", and "discipline and culture of high schools." Researcher reviewed studies published in top management, psychology, and education fields across several databases including Google Scholar, Griffith Library, Emerald Full text, ProQuest, Science Direct, and Scopus. A total of 28,120 studies were identified with a customer search ranging between 2014 to 2020 . 
The main aim of this review paper is to identify the most recent research gaps in culture and student discipline of secondary schools. Therefore, a period of six years been selected to avoid using outdated content in the reviewing process. This can be further justified based on the precedents of reviews that focussed on only a five to six-year review period with findings indicating the most recent research gaps (Jarquin, Wiggins, Schieve, \& Naarden, 2011; Park, Satoh, Miki, Urushihara, \& Sawada, 2015; Setati, Chitera, \& Essien, 2009).

All results were limited to English only peer-reviewed studies. Initially, the author grouped the identified studies and removed the duplicated records of 9,718 studies from the system. The remaining were assessed using the below mentioned criteria. Studies that were out of the reviewing scope such as studies conducted on elementary schools, and in tertiary and university contexts, and other studies that do not contribute to the secondary school sector were removed from the process. The studies published in either ' $\mathrm{B}$ ' or above in ABDC ranking or ' $\mathrm{Q} 2$ ' or above in SC imago ranking were selected for the final reviewing. Several studies also considered the higher impact factor of the journal and contribution of the paper. Finally, a total of 60 studies were identified as qualified. Figure 1 further illustrates the inclusion and exclusion criteria used for this review. 
Figure 1: Flowchart of the literature search process (PRISMA)

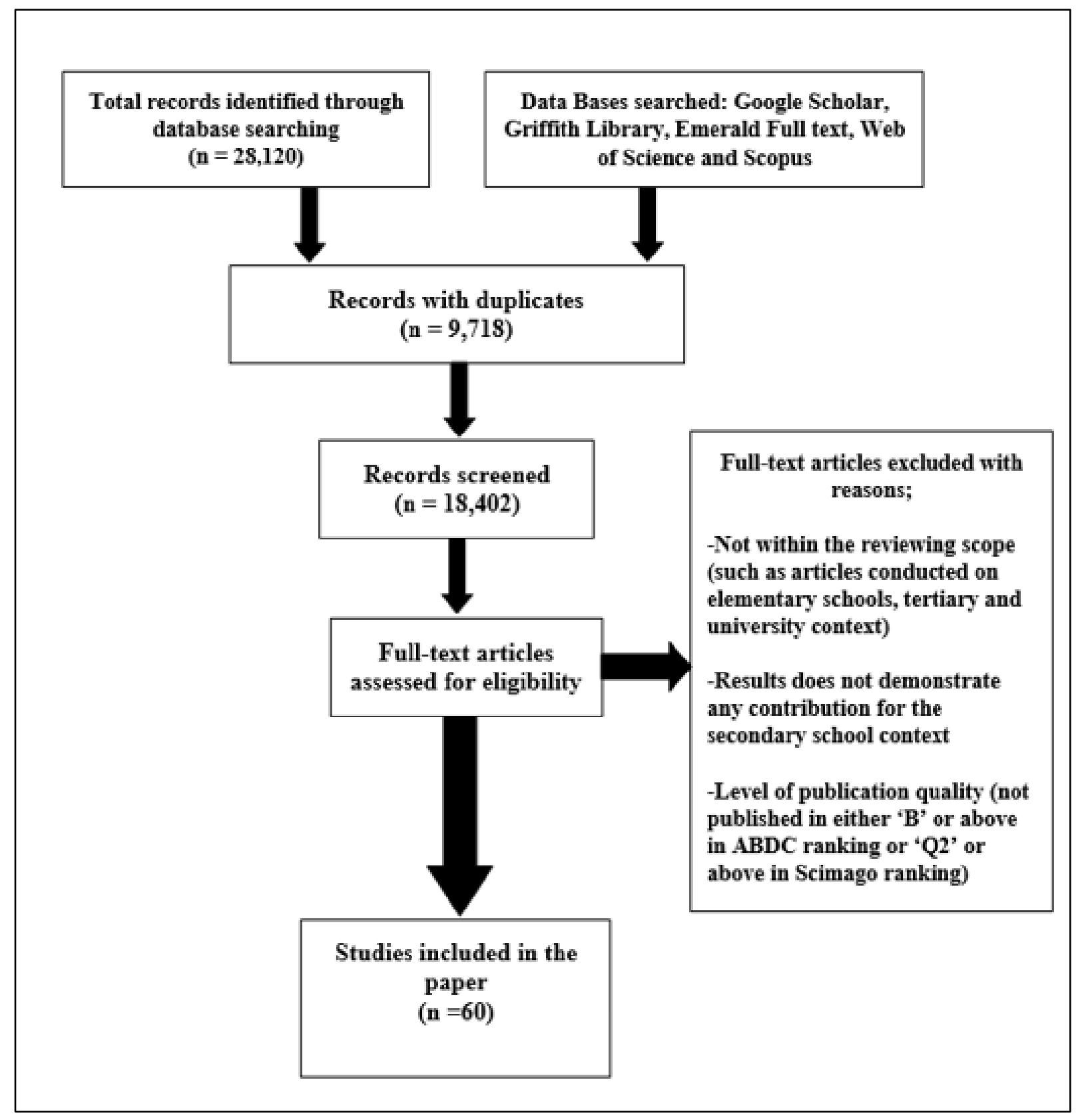

Source: Developed by author

These final 60 studies include journal papers, book reviews, and thesis projects. These were summarised with six sections as Source, Journal, Focus, Theory, Data type, and Findings using Table 1A (Please refer Appendices). 


\section{Thematic future research agenda}

As in Table 1A, the author reviewed each study carefully, and identified six themes that denote future research avenues in the context of secondary school student discipline in a cross-cultural context. These themes are 1) Punishment, 2) Restorative practices, 3) Racial disparities, 4) Competitiveness, 5) School Climate, and 6) Secondary school student discipline in a crosscultural context.

\section{Punishment}

When considering the first theme of 'punishment', it was identified that East and South Asian countries such as India (Deb, Kumar, Holden, \& Simpson Rowe, 2017), Bangladesh (Mohiuddin, Khatun, \& Al-Kamal, 2012), Korea, Japan, and Taiwan (Baumann et al., 2020) has a higher level of academic performance due to high levels of discipline in the classrooms. Even this aspect is influenced by several school practices such as teachers checking homework (Baumann et al., 2020), wearing school uniforms (Baumann \& Krskova, 2016; Baumann et al., 2020) and even due to school corporal punishments (Gershoff, 2017b; Ssenyonga, Hermenau, Nkuba, \& Hecker, 2019). It is highly recommended for future researchers to examine the relationship between stricter school policies and stronger academic performance among students by combining experimental research approaches as well as school corporal punishments and physical safety of children.

It appears that countries with stricter school policies have often stronger academic performance among students (Baumann \& Krskova, 2016; Baumann et al., 2020). However, very few studies have assessed the relationship between stricter school policies and stronger academic performance among students (Baumann \& Krskova, 2016; Baumann et al., 2020). Further, Anyon, Zhang, and Hazel (2016) pointed out the need for experimental research on reducing students' risk of exclusionary discipline infractions. Therefore, it is highly recommended for future researchers to examine the relationship between stricter school policies and stronger academic performance among students by combining experimental research approaches.

Moreover, corporal punishment of children in schools has been the focus of many researchers and policymakers around the world (Gershoff, 2017b). For instance, in some parts of East Asia and in some US states, corporal punishment is highly used by teachers (Gershoff, 2017b; Ssenyonga et al., 2019). Although much is known about parents' use of corporal punishment, to date, researchers have not focussed on the school corporal punishments in the area of 
physical safety of children (Gershoff, 2017b; Ssenyonga et al., 2019). Therefore, Anyon et al. (2014) identified that experimental trials of alternatives to suspension and classroom-based interventions, like restorative approaches that appear to reduce students' risk of school exclusion, as it is necessary with more research focussing on the efficacy of these approaches in reducing racial disparities in school discipline outcomes.

\section{Restorative practices (RP)}

The second theme of 'restorative practices', is an alternative solution to school discipline and a way to engage students who misbehave in school. Restorative practices can be considered an alternative approach to school discipline and a way to engage students who misbehave in school (Mayworm, Sharkey, Hunnicutt, \& Schiedel, 2016). Recently, researchers have identified that restorative practices are an effective mechanism to reduce suspension and recidivism, which act as viable alternatives to punitive discipline procedures (Mansfield et al., 2018) as well as improves student-teacher relationships and reduces the racial disciplinary gap (Gregory, Clawson, Davis, \& Gerewitz, 2016; Gregory \& Fergus, 2017). In addition, restorative and in-school suspensions shield learners from out-of-school suspensions (Anyon et al., 2014). Although researchers focussed on implementation of restorative practices in schools, the studies focussed on measuring the effectiveness of these implemented outcomes fall within an under-researched area. This is because measuring the outcomes is often challenging, as they can include elements such as environment, culture, and relationships (Anyon et al., 2014). Most of the literature centres around contextual study of individual experiences while examining restorative activities (Raffenbeul, 2019). Very little evidence is available to show the correlation with processes and the effect on student conduct or discipline.

Additionally, most restorative justice research lacks rigorous impact evaluation studies to assess restorative justice outcomes (Schiff, 2018). Up to date, there is one five-year randomised trial in process that is studying the restorative justice impact on developmental outcomes and problem behaviours (Acosta et al., 2016). Further, Bevington (2015) identified the need for more empirical research on the impact of restorative justice in educational settings, including causality. The tools to be used as RP strategies and the influence of culture change on RP strategies is another under-researched area (Bevington, 2015).

Further, Kline (2016) mentioned future researchers should explore teachers' classroom management skills as well as their perceptions of acceptable classroom behaviour. Similarly, 
Gregory et al. (2016) indicated that up-to-date studies were unable to explain why some teachers implemented RP more than other teachers. Explanatory factors to consider in future include conflict or correspondence between the underlying values of RP and teachers' approach to discipline and the degree to which teachers perceive that RP impedes or facilitates instruction (Gregory et al., 2016). Future research should explore possible mediation mechanisms that can help explain why well-implemented RP has been linked to decreased dependence on exclusionary discipline, especially among African American and Latino students.

Mayworm et al. (2016) mentioned that research on the effectiveness of teacher training programs that focus on discipline and restorative justice. Based on the literature, it is evident that more studies are necessary to identify most effective restorative justice approaches through proper teacher training strategies. Similarly, Murphy (2018) indicated the need for future research to study the critical aspects of restorative justice. While many experts and professionals contribute to the whole-school method, it is important to research and compare the findings from the whole-school and add-on approach to recognize commonalities and differences.

\section{Racial disparities}

The third theme of 'racial disparities' is a common research area in secondary school education research (Bottiani, Bradshaw, \& Mendelson, 2016). However, more research is needed to check the association between students' perceptions of teachers' success expectancies and academic outcomes, as perceived discrimination between white and black students in the United States secondary schools may cause students to mistrust the academic performance assessment process (Bottiani et al., 2016). Furthermore, future research should examine the interaction of faculty and student diversity as contextual influences on racial differences in student perceptions of school support and school equity in particular (Bottiani et al., 2016) as additional research is needed to understand how students' racial backgrounds interact with the school context to shape their perceptions of school support.

Bradshaw, Mitchell, O'Brennan, and Leaf (2010) focussed their research exclusively on black and white students and teachers and identified the need to replicate these findings with greater diversity. The racial discipline gap was not totally eliminated in classrooms with high RP implementation, which raises many questions about whether future consultants can further boost these teachers' RP implementation or whether they need to offer other approaches to 
improve teacher-student relationships (Gregory \& Fergus, 2017). Additionally, Cornell and Bradshaw (2015) in their literature review, emphasised the importance of bullying prevention in secondary schools, noting that this bullying occurs as a result of racial disparities. Nevertheless, bullying prevention research should focus on ways to change student behaviour, classrooms, and school-level polices in order to prevent bullying (Cornell \& Bradshaw, 2015).

Okonofua and Eberhardt (2015) proved experimentally, for the first time, that teacher responses can contribute to racial disparities in discipline. Consequently, teacher responses may also tend to drive racial disparities in student attitudes, such as teacher differential treatment; this can inspire black students to some degree to persistent misconduct. In future studies, this possibility is worth exploring. Existing research suggests racial disproportionality persists in school discipline, even when positive discipline is substituted for zero tolerance policies. However, to date, no proper method has been identified to link these areas for further investigation (Lustick, 2017). Martin and Smith (2017) compared African American girls to white girls, to determine if subjective discipline and social control of black girls leads to eventual school dropout. Using the findings of this study, future researchers can train new teachers or guide teacher education programs.

\section{Competitiveness}

The fourth theme indicated the 'competitiveness' related studies in secondary school education research. Competition is extremely strong in education. Baumann and Krskova (2016) identified many positive aspects of school discipline across five geographic clusters, with East Asia leading the way using the PISA data. Major findings indicated significant differences in discipline for low-, medium-, and high-performing students. Peak-performing students had the highest level of discipline. Students wearing a uniform listened better, with lower teacher waiting times. These findings further illustrates the relationship between student disciplines and competitiveness as previous research on drivers of academic performance mainly focussed on the amount of funding provided for education (Jensen, Reichl, \& Kemp, 2011), classroom size (Ajayi, Audu, \& Ajayi, 2017; Finn, Gerber, \& Boyd-Zaharias, 2005; Hoxby, 2000), hours of schooling (Huebener \& Marcus, 2017; Ray \& Lancaster, 2005), and teacher quality (Agasisti \& Longobardi, 2014; Anttila \& Väänänen, 2015; Gershoff, 2016; Gittins, 2006; Mischel, 1976) without considering competitiveness as a major factor. 
Further, Krskova and Baumann (2017) found the relative importance of school discipline (88 per cent) in comparison to education investment (12 per cent) on educational performance, with both variables found to be significantly associated with competitiveness directly. The schools or countries with stricter school discipline methods often performed academically well (Baumann et al., 2020). However, what has been missing in the current literature is the proper links on discipline to performance, and performance to competitiveness. Currently, Baumann et al. (2020) is the first to link discipline to performance, and performance to competitiveness in the educational context by introducing a new research model named CDC (Confucianism, Discipline, and Competitiveness).

Similarly, Krskova (2015) examined the links between everyday school operations that result in various levels of school discipline, national financial investment in education, academic performance measured every three years globally by the OECD's Programme for International Student Assessment (PISA) assessment, and national competitiveness levels. This study identified a new conceptual framework combining school discipline, education investment, educational performance, and competitiveness into one model for the first time, and the subsequent testing of the overall model has provided empirical support for the proposition that school discipline has an indirect impact on competitiveness (Krskova \& Baumann, 2017).

Previous scholars, however, have found that there are variations in discipline levels between geographic regions (Baumann, Tung, \& Hamin, 2012) and academic results performance (Baumann \& Krskova, 2016). The longitudinal relation between education and competitiveness in different regions of the world needs to be evaluated in further studies (Baumann \& Winzar, 2016). This leads to another future research perspective on, investigating the extent to which different geographic regions differ in relation to school discipline and its impact on educational performance and competitiveness.

\section{School culture}

The fifth theme indicated the 'school culture'. A school's definition of culture defines the characteristics of a school as it represents profound trends of values, beliefs, and practices that have been developed over its history (Deal \& Peterson, 1990). When considering the school climate or culture, research on encouraging resilient students (those who can obtain good academic results despite coming from a disadvantaged socio-economic background) is less available (Agasisti \& Longobardi, 2014). Moreover, Anttila and Väänänen (2015) pointed out 
that teacher emotional demands are another area lacking attention. Bartlett, Mendenhall, and Ghaffar (2017) found gaps on studies about existing support systems for refugee students in middle schools of the United States. Another under-researched field in American schools is teenage development correlated with school discipline (Amemiya, Mortenson, \& Wang, 2020). The first exploratory study that explored the extent to which students with Aboriginal status receive disproportionate rates of office discipline referrals (ODRs) and more severe administrative consequences relative to students without Aboriginal status was conducted in Canada by Greflund, McIntosh, Mercer, and May (2014). This study can be replicated by other researchers in other countries.

Even though many researchers have studied the role of school principal on learner discipline, how the type of leadership may influence learner discipline and which type of leadership contributes to positive learner behaviour is under researched (Belle, 2016). Future studies are necessary to investigate the role of disciplinary climate in the classroom and student math selfefficacy on math achievement (Cheema \& Kitsantas, 2014). Childs, Kincaid, George, and Gage (2016) examined the relationship between School-Wide Implementation of Positive Behaviour Intervention and Supports (SWIPBIS) and student discipline outcomes of schools in Florida. This study can be replicated by future researchers while adding more time points and assessing potential deceleration of discipline data across time. More cross-cultural research is necessary to examine the main effect of disciplinary climate strength on student reading performance, and its moderating effect on the relationship between climate level and student reading performance (Guo, Li, \& Zhang, 2018). Lawa et al. (2019) identified several daily school activities that affect school discipline, such as morning ceremonies, sports activities, etc. They recommended replicating this study for different cultural contexts to identify the different daily school activities that affect the student discipline in different countries.

A study regarding the role of school culture on school improvement and school reform initiatives found that school leadership and teachers strengthen the culture of the school. With the intent of improving teaching practice and student learning, this is a promising school reform strategy (Ohlson, Swanson, Adams, \& Byrd, 2016). Further, Ohlson et al. (2016) suggested replicating the same study with different cultural settings. Similarly, student performance varies dramatically across countries, but little is understood about the role of teacher quality in explaining these differences (Hanushek, Piopiunik, \& Wiederhold, 2014). Even this paper used new international data from the Programme for the International Assessment of Adult 
Competencies (PIAAC) that allow, for the first time, to quantify teacher skills in numeracy and literacy. This study can be replicated for different countries.

\section{Student discipline}

Finally, the sixth theme indicated the 'student discipline'. School discipline applies to school policies and techniques for the control of student actions and activities used to foster self-discipline in school (Gershoff, 2017a). A growing body of research has examined and explored the role of culture and discipline in secondary schools in a cross-cultural context, as shown in Table 1A. There are variations between every country regarding discipline and culture, therefore different countries should focus on different aspects of student discipline. This could be further justified as follows; for example, in Kenya, researchers suggest further studies to develop strategies that can effectively handle most of the indiscipline cases in secondary schools (Njoroge \& Nyabuto, 2014). They encourage researchers to investigate whether the anticipation of self-approval motivates or demotivates the behaviour of students (Salgong, Ngumi, \& Chege, 2016) and to identify strategies to enhance student discipline in public secondary schools (Asiligwa, 2015). More studies are required on resources of schools for the guidance and counselling of students, legal and policy framework, lack of trained teacher counsellors (Wambua, 2017), and strict workloads of teachers that makes it difficult for guidance and counselling to succeed in promoting student discipline (Salgong et al., 2016).

For Tanzania, studies are necessary to examine divergent perspectives on what constitutes disciplinary measures, social control, and corporal punishment of students in secondary schools (Semali \& Vumilia, 2016). For Nigeria, Ajayi et al. (2017) identified that a class size of a maximum of 40:1 student-teacher ratio significantly influences classroom discipline, engagement, and communication. However, this finding has not been further researched by Nigerian researchers. When considering Indonesia, more studies on students' reading habits in raising discipline is necessary (Wandasari, Kristiawan, \& Arafat, 2019). Studies on teachers that show that their approach to managing the actions of students should be more intense and that they should work well with parents are also under researched (Lawa et al., 2019). Further, in Finland, future studies need to concentrate more on emotional work, which plays an important role in developing the kind of learning atmosphere that is in line with the progressive educational goals of fostering the personal growth of students and their free self-expression (Anttila \& Väänänen, 2015). 
For the United States, the relationship between student discipline history and special education identification, as well as the relationship between student achievement and discipline, is also identified as an under-researched area (Anderson \& Ritter, 2015). The authors, Martin and Smith (2017) mentioned the need for more studies on professional development sessions for in-service teachers in the United States. Cornell and Bradshaw (2015) emphasised the importance of research on safe and supportive school climates. Peguero and Bracy (2015) also mentioned future researchers should consider the role that community-level variables play in shaping school climate and consequently, in influencing who drops out at a disproportionate number. The studies on diversity in schools, such as in-service teachers, pre-service teachers, and school leadership preparation programs with a more dynamic view of culture, is necessary for the United States (Bartlett et al., 2017). The role of school culture on the United States' school reform initiatives also requires more research (Ohlson et al., 2016). The United States has the world's highest prison population rate. Consequently, taxpayers spend more than several billion dollars a year on incarceration expenses. Eliminating discriminatory and punitive practices should be the priority of each school board (Thompson, 2016).

However, only one study to date has been published to examine the country's legal structure for school education. This research was a qualitative study performed using observations and interviews. Wandasari et al. (2019) evaluated the Regulation Minister of Education and Culture Number 23 of 2015 in the state high school, Penukal Abab Lematang Ilir (PALI). This study can be replicated by other countries to identify the ongoing issues of the country about secondary school education. For China, Wang (2016) suggested conducting more research on instructional leadership and broad-based teacher leadership support, which results in successful learning and teaching. For Rwanda, some strategies such as guidance and counselling should be implemented in schools by having qualified teachers in guidance and counselling, which are lacking at the moment. Parents need to be closely involved in the behaviour of their children. Therefore, engagement strategies should be devised; for example, parent and teacher meetings, parent administration meetings, clear communication channels established between parents and school, among others. Therefore, Otara and Uwanyirigira (2018) suggested more engagement strategies related to research for Rwanda. Finally, school violence by Ugandan teachers emphasised that teacher training requires the integration of effective stress management, nonviolent discipline strategies, and attitude change into the curriculum, which needs further attention. 


\section{Conclusion}

The purpose of this systematic literature review was to identify future research perspectives regarding culture and discipline in secondary schools in a cross-cultural context. Consequently, literature published in top management, psychology, and educational sources during the period of 2014 to 2020 has been reviewed. As a result of this systematic literature review, the author identified six major themes as 1) Punishment, 2) Restorative practices, 3) Racial disparities, 4) Competitiveness, 5) School climate, and 6) student discipline in a cross-cultural context. Based on this, the author has proposed several future research directions under these six areas. To the best of the authors' knowledge, this study can be considered as the first systematic literature review conducted using PRISMA guidelines on culture and discipline of secondary schools in a cross-cultural context with several future research insights.

\section{References}

Acosta, J., Chinman, M., Ebener, P., Phillips, A., Xenakis, L., \& Malone, P. (2016). A clusterrandomized trial of restorative practices: An illustration to spur high-quality research and evaluation. Journal of Educational Psychological Consultation, 26(4), 413-430.

Agasisti, \& Longobardi. (2014). Educational institutions, resources, and students' resiliency: an empirical study about OECD countries.

Ajayi, Audu, \& Ajayi. (2017). Influence of class size on students' classroom discipline, engagement and communication: a case study of senior secondary schools in Ekiti state, Nigeria. Sky Journal of Educational Research, 5(5), 034-041.

Amemiya, Mortenson, \& Wang. (2020). Minor infractions are not minor: School infractions for minor misconduct may increase adolescents' defiant behavior and contribute to racial disparities in school discipline. American Psychologist, 75(1), 23.

Anderson, \& Ritter. (2015). Discipline disproportionalities in schools: The relationship between student characteristics and school disciplinary outcomes. EDRE Working Paper, 8, 24.

Anttila, \& Väänänen. (2015). From authority figure to emotion worker: Attitudes towards school discipline in Finnish schoolteachers' journals from the 1950s to the 1980s. Pedagogy, Culture Society, 23(4), 555-574.

Anyon, Jenson, Altschul, Farrar, McQueen, Greer, . . Simmons. (2014). The persistent effect of race and the promise of alternatives to suspension in school discipline outcomes. Children Youth Services Review, 44(1), 379-386.

Anyon, Zhang, \& Hazel. (2016). Race, exclusionary discipline, and connectedness to adults in secondary schools. American Journal of Community Psychology, 57(3-4), 342-352.

Arifin. (2015). The Influence of Competence, Motivation, and Organisational Culture to High School Teacher Job Satisfaction and Performance. International Education Studies, 8(1), 38-45.

Asiligwa, R. (2015). Contribution of students' councils to student discipline in Public secondary schools in Hamisi sub-county, Kenya. Mount Kenya University, erepository.mku.ac.ke.

Balfanz, \& Fox. (2014). Sent home and put off-track: The antecedents, disproportionalities, and consequences of being suspended in the ninth grade. Journal of Applied Research on Children: Informing Policy for Children at Risk, 5(2), 13.

Bartlett, Mendenhall, \& Ghaffar. (2017). Culture in acculturation: Refugee youth's schooling experiences in international schools in New York City. International Journal of Intercultural Relations, 60, 109-119. 
Baumann, \& Hamin. (2011). The role of culture, competitiveness and economic performance in explaining academic performance: a global market analysis for international student segmentation. Journal of Marketing for Higher Education, 21(2), 181-201.

Baumann, \& Krskova. (2016). School discipline, school uniforms and academic performance. International Journal of Educational Management.

Baumann, Tung, \& Hamin. (2012). "Jade will never become a work of art without being carved: western versus Chinese attitudes towards discipline in education and society". Virginia Review of Asian Studies, 10(1), 1-17.

Baumann, \& Winzar. (2016). The role of secondary education in explaining competitiveness. Asia Pacific Journal of Education, 36(1), 13-30.

Baumann, Winzar, \& Viengkham. (2020). Confucianism, discipline, and competitiveness (Vol. 1). United States: Routledge.

Bechuke, \& Debeila. (2012). Applying choice theory in fostering discipline: Managing and modifying challenging learners behaviours in South African schools. International Journal of Humanities Social Science, 2(22), 240-255.

Belle. (2016). The role of principals in maintaining effective discipline among learners in selected Mauritian state secondary schools: An education management model. (Doctoral thesis), University of South Africa, Unpublished Doctoral thesis. .

Benard, B. (2004). Resiliency: What we have learned (Vol. 2). books.google.com: WestEd.

Bevington. (2015). Appreciative evaluation of restorative approaches in schools. Pastoral Care in Education, 33(2), 105-115.

Bottiani, Bradshaw, \& Mendelson. (2016). Inequality in Black and White high school students' perceptions of school support: An examination of race in context. Journal of youth adolescence, 45(6), 1176-1191.

Bradshaw, C., Mitchell, M., O'Brennan, L., \& Leaf, P. (2010). Multilevel exploration of factors contributing to the overrepresentation of black students in office disciplinary referrals. Journal of Educational Psychology, 102(2), 508.

Brown, \& Kozlowski. (1999). Dispersion theory: Moving beyond a dichotomous conceptualization of emergent organizational phenomena. Paper presented at the 14th annual meeting of the Society of Industrial and Organizational Psychology, Atlanta, GA.

Cameron. (2006). Managing school discipline and implications for school social workers: A review of the literature. Children Schools, 28(4), 219-227.

Caro, Lenkeit, \& Kyriakides. (2016). Teaching strategies and differential effectiveness across learning contexts: Evidence from PISA 2012. Studies in Educational Evaluation, 49(1), 30-41.

Chao. (1994). Beyond parental control and authoritarian parenting style: Understanding Chinese parenting through the cultural notion of training. Child development, 65(4), 1111-1119.

Cheema, J., \& Kitsantas, A. (2014). Influences of disciplinary classroom climate on high school student self-efficacy and mathematics achievement: A look at gender and racial-ethnic differences. International Journal of Science Mathematics Education, 12(5), 1261-1279.

Chen. (2005). Cultural Perspectives on Student Behaviors: A Study of American and Chinese Students. Online Submission, 2(1), 25-32.

Chi, Liu, Wang, \& Won Han. (2018). Moderation of the effects of scientific inquiry activities on low SES students' PISA 2015 science achievement by school teacher support and disciplinary climate in science classroom across gender. International Journal of Science Education, 40(11), 1284-1304.

Childs, Kincaid, George, \& Gage. (2016). The relationship between school-wide implementation of positive behavior intervention and supports and student discipline outcomes. Journal of Positive Behavior Interventions, 18(2), 89-99.

Chiu, \& Chow. (2011). Classroom discipline across forty-one countries: School, economic, and cultural differences. Journal of Cross-Cultural Psychology, 42(3), 516-533.

Cobley. (2008). Culture: Definitions and concepts. The International Encyclopedia of Communication, l(1), 28.

Cornell, \& Bradshaw. (2015). From a culture of bullying to a climate of support: The evolution of bullying prevention and research. School Psychology Review, 44(4), 499-503. 
Crenshaw, K. (1990). Mapping the margins: Intersectionality, identity politics, and violence against women of color. 43, 1241.

Deal, T., \& Peterson, K. (1990). The principal's role in shaping school culture: US Department of Education, Office of Educational Research and Improvement.

Deb, S., Kumar, A., Holden, G., \& Simpson Rowe, L. (2017). School corporal punishment, family tension, and students' internalizing problems: Evidence from India. School psychology international, 38(1), 60-77.

Fergus, E. (2019). Confronting our beliefs about poverty and discipline. Phi Delta Kappan, 100(5), 31-34.

Finn, J., Gerber, S., \& Boyd-Zaharias, J. (2005). Small classes in the early grades, academic achievement, and graduating from high school. Journal of Educational Psychology, 97(2), 214.

Gershoff. (2016). Child Outcomes: Old Controversies New Meta-Analyses. Journal of Family Psychology, 453-469.

Gershoff. (2017a). School corporal punishment in global perspective: prevalence, outcomes, and efforts at intervention. Psychology, health medicine, 22(sup1), 224-239.

Gershoff. (2017b). School corporal punishment in global perspective: prevalence, outcomes, and efforts at intervention. Psychology, health medicine, 22(sup1), 224-239.

Gittins. (2006). Violence Reduction in Schools--how to Make a Difference: A Handbook (Vol. 795). books.google.com: Council of Europe.

Greflund, McIntosh, Mercer, \& May. (2014). Examining disproportionality in school discipline for Aboriginal students in schools implementing PBIS. Canadian Journal of School Psychology, 29(3), 213-235.

Gregory, Clawson, Davis, \& Gerewitz. (2016). The promise of restorative practices to transform teacher-student relationships and achieve equity in school discipline. Journal of Educational Psychological Consultation, 26(4), 325-353.

Gregory, \& Fergus. (2017). Social and emotional learning and equity in school discipline. The Future of Children, 117-136.

Guo, Li, \& Zhang. (2018). A multilevel analysis of the effects of disciplinary climate strength on student reading performance. Asia Pacific Education Review, 19(1), 1-15.

Hanushek, Piopiunik, \& Wiederhold. (2014). The Impact of Teacher Skills on Student Performance across Countries. cesifo-group.de.

Horton. (2015). Note passing and gendered discipline in Vietnamese schools. British Journal of Sociology of Education, 36(4), 526-541.

Hoxby, C. (2000). The effects of class size on student achievement: New evidence from population variation. The Quarterly Journal of Economics, 115(4), 1239-1285.

Hue. (2001). A study of the relationship between school guidance and discipline in Hong Kong secondary schools. Institute of Education, University of London, discovery.ucl.ac.uk.

Huebener, M., \& Marcus, J. (2017). Compressing instruction time into fewer years of schooling and the impact on student performance. Economics of Education Review, 58(2), 1-14.

Jain, Bassey, Brown, \& Kalra. (2014). Restorative Justice in Oakland Schools: an Effective Strategy to Reduce Racially Disproprotionate Discipline, Suspensions, and Improve Academic Outcomes. Oakland Unified School District.

Jarquin, Wiggins, Schieve, \& Naarden. (2011). Racial disparities in community identification of autism spectrum disorders over time; Metropolitan Atlanta, Georgia, 2000-2006. Journal of Developmental Behavioral Pediatrics, 32(3), 179-187.

Jenkins, A., \& Ueno, A. (2017). Classroom disciplinary climate in secondary schools in England: What is the real picture? British Educational Research Journal, 43(1), 124-150.

Jensen, B., Reichl, J., \& Kemp, A. (2011). The real issue in school funding: An analysis of increasing government school expenditure and declining performance. Australian Economic Review, 44(3), 321-329.

Jerrim, Oliver, \& Sims. (2020). The relationship between inquiry-based teaching and students' achievement. New evidence from a longitudinal PISA study in England. Learning Instruction, l(1), 101310. 
Kline. (2016). Can restorative practices help to reduce disparities in school discipline data? A review of the literature. Multicultural Perspectives, 18(2), 97-102.

Krskova, H. (2015). The Relative Importance of School Discipline and Education Investment on Competitiveness: The Mediating Role of Educational Performance. (Masters of Research ), Macquarie University, researchonline.mq.edu.au.

Krskova, H., \& Baumann, C. (2017). School discipline, investment, competitiveness and mediating educational performance. International Journal of Educational Management, 31(3), 27.

Krskova, H., Wood, L., Breyer, Y., \& Baumann, C. (2020). FIRST: principles of discipline for 21st Century skills. In L. Wood, L. P. Tan, Y. Breyer, \& S. Hawse (Eds.), Industry and Higher Education (pp. 265-289). Industry and Higher Education: Springer.

Kuczynski, Marshall, \& Schell. (1997). Value socialization in a bidirectional context. In Grusec \& Kuczynski (Eds.), Parenting children's internalization of values: A handbook of contemporary theory (pp. 23-50): John Wiley \& Sons Inc.

Lawa, Wiyono, \& Supriyanto. (2019). Disciplining Culture Management of Middle School Students in the Eastern of Indonesia. Jurnal Pendidikan Humaniora, 7(3), 7.

Losen, D. (2014). Closing the school discipline gap: Equitable remedies for excessive exclusion (Vol. 1): Teachers College Press.

Lustick, H. (2017). Making discipline relevant: Toward a theory of culturally responsive positive schoolwide discipline. Race Ethnicity Education, 20(5), 681-695.

Mansfield, Fowler, \& Rainbolt. (2018). The potential of restorative practices to ameliorate discipline gaps: The story of one high school's leadership team. Educational Administration Quarterly, 54(2), 303-323.

Martin, \& Smith. (2017). Subjective Discipline and the Social Control of Black Girls in Pipeline Schools. Journal of Urban Learning, Teaching and Research, 13(1), 63-72.

Mayworm, Sharkey, Hunnicutt, \& Schiedel. (2016). Teacher consultation to enhance implementation of school-based restorative justice. Journal of Educational Psychological Consultation, 26(4), $385-412$.

Mischel. (1976). Towards a cognitive social model learning reconceptualization of personality. Interactional psychology and personality.

Mohiuddin, H., Khatun, A., \& Al-Kamal, M. (2012). Corporal Punishment in Bangladesh School System: An Analytical Appraisal of Elimination Strategy Directions. ASA University Review, $6(2)$.

Murphy. (2018). A Relational Approach to Discipline: A Comparative Case Study of Restorative Justice Implementation in US Secondary Schools. (Doctoral dissertation), University of Southern California, University of Southern California.

Nakpodia. (2010). Teachers disciplinary approaches to students discipline problems in Nigerian secondary schools. International NGO Journal, 5(6), 144-151.

Ning, Damme, Den, Yang, \& Gielen. (2015). The influence of classroom disciplinary climate of schools on reading achievement: A cross-country comparative study. School Effectiveness School Improvement, 26(4), 586-611.

Njoroge, \& Nyabuto. (2014). Discipline as a factor in academic performance in Kenya. Journal of Educational and Social Research, 4(1), 289-289.

Ohlson, Swanson, Adams, \& Byrd. (2016). A Culture of Success--Examining School Culture and Student Outcomes via a Performance Framework. Journal of Education Learning, 5(1), 114127.

Okonofua, \& Eberhardt. (2015). Two strikes: Race and the disciplining of young students. Psychological science, 26(5), 617-624.

Otara, A., \& Uwanyirigira, F. (2018). Administrative strategies in mitigating middle level students' discipline in public secondary schools in Rwanda. Journal of Education Practice, 9(21), 1-13.

Park, \& Abelmann. (2004). Class and cosmopolitan striving: Mothers' management of English education in South Korea. Anthropological quarterly, 1(1), 645-672.

Park, Satoh, Miki, Urushihara, \& Sawada. (2015). Medications associated with falls in older people: systematic review of publications from a recent 5-year period. European journal of clinical pharmacology, 71(12), 1429-1440. 
Peguero, \& Bracy. (2015). School order, justice, and education: Climate, discipline practices, and dropping out. Journal of research on adolescence, 25(3), 412-426.

Raffenbeul. (2019). The Impact of Restorative Practices on Discipline Data and Procedures in Schools. from The Repository at St. Cloud State University

Ray, R., \& Lancaster, G. (2005). The impact of children's work on schooling: Multi-country evidence. International Labour Review, 144, 189.

Salgong, Ngumi, \& Chege. (2016). The Role of Guidance and Counseling in Enhancing Student Discipline in Secondary Schools in Koibatek District. Journal of Education Practice, 7(13), 142-151.

Sandoval, \& Białowolski. (2016). Factors and conditions promoting academic resilience: a TIMSSbased analysis of five Asian education systems. Asia Pacific Education Review, 17(3), 511520.

Schiff, M. (2018). Can restorative justice disrupt the 'school-to-prison pipeline?'. Contemporary Justice Review, 21(2), 121-139.

Semali, L., \& Vumilia, P. (2016). Challenges Facing Teachers' Attempts to Enhance Learners' Discipline in Tanzania's Secondary Schools. World Journal of Education, 6(1), 50-67.

Setati, Chitera, \& Essien. (2009). Research on multilingualism in mathematics education in South Africa: 2000-2007. African Journal of Research in Mathematics, Science Technology Education, 13(sup1), 65-80.

Skinner, E., \& Pitzer, J. (2012). Developmental dynamics of student engagement, coping, and everyday resilience. In Handbook of research on student engagement (pp. 21-44). Springer, Boston, MA.: Springer.

Sortkær, \& Reimer. (2016). Disciplinary climate and student achievement: Evidence from schools and classrooms. from Danish National Research Database

Sortkær, \& Reimer. (2018). Classroom disciplinary climate of schools and gender-evidence from the Nordic countries. School Effectiveness School Improvement, 29(4), 511-528.

Ssenyonga, J., Hermenau, K., Nkuba, M., \& Hecker, T. (2019). Stress and positive attitudes towards violent discipline are associated with school violence by Ugandan teachers. Child abuse neglect, 93(1), 15-26.

Thompson. (2016). Eliminating zero tolerance policies in schools: Miami-Dade county public schools' approach. from HeinOnline

Vincent, Sprague, Pavel, Tobin, \& Gau. (2015). Effectiveness of schoolwide positive behavior interventions and supports in reducing racially inequitable disciplinary exclusion. Closing the school discipline gap: Equitable remedies for excessive exclusion, 207-221.

Wambua. (2017). Influence of principals' participatory management practices on students' discipline in secondary schools in Machakos County, Kenya. (Master's Thesis), University of Nairobi, Kenya erepository.uonbi.ac.ke.

Wandasari, Kristiawan, \& Arafat. (2019). Policy Evaluation of School's Literacy Movement on Improving Discipline of State High School Students. International Journal of Scientific Technology Research, 8(4), 190-198.

Wang. (2016). School leadership and professional learning community: Case study of two senior high schools in Northeast China. Asia Pacific Journal of Education, 36(2), 202-216.

Weed. (2005). "Meta interpretation": A method for the interpretive synthesis of qualitative research. Paper presented at the Forum Qualitative Sozialforschung/Forum: Qualitative Social Research, Forum Qualitative Sozialforschung.

Yamamoto, \& Brinton. (2010). Cultural capital in East Asian educational systems: The case of Japan. Sociology of Education, 83(1), 67-83. 


\section{Appendices: Table 1A}

Summary of the key studies reviewed in this paper

\begin{tabular}{|c|c|c|c|c|c|c|}
\hline & Source & $\begin{array}{l}\text { Journal/ } \\
\text { Book/Theses }\end{array}$ & Theory & Data type & $\begin{array}{l}\text { Emerged } \\
\text { Themes }\end{array}$ & Findings on discipline constructs \\
\hline 1 & $\begin{array}{l}\text { Acosta et } \\
\text { al. }(2016)\end{array}$ & $\begin{array}{l}\text { Journal of } \\
\text { Educational \& } \\
\text { Psychological } \\
\text { Consultation }\end{array}$ & $\begin{array}{l}\text { Ecological } \\
\text { Systems } \\
\text { Theory }\end{array}$ & Surveys & $\begin{array}{l}\text { Restorative } \\
\text { practices }\end{array}$ & $\begin{array}{l}\text { - Advance the theory of positive youth development by empirically validating } \\
\text { that restorative justice principles affects students' positive developmental } \\
\text { outcomes }\end{array}$ \\
\hline 2 & $\begin{array}{l}\text { Ajayi et al. } \\
(2017)\end{array}$ & $\begin{array}{l}\text { Sky Journal of } \\
\text { Educational } \\
\text { Research }\end{array}$ & $\begin{array}{l}\text { Social } \\
\text { Constructivist } \\
\text { Theory }\end{array}$ & Surveys & Competitiveness & $\begin{array}{l}\text {-Smaller class sizes, with less than } 40 \text { students, have a favourable influence } \\
\text { on classroom discipline, engagement, and communication }\end{array}$ \\
\hline 3 & $\begin{array}{l}\text { Anderson } \\
\text { and Ritter } \\
(2015)\end{array}$ & $\begin{array}{l}\text { Working paper } \\
\text { of University } \\
\text { of Arkansas }\end{array}$ & ND & $\begin{array}{l}\text { Arkansas } \\
\text { Department of } \\
\text { Education }\end{array}$ & $\begin{array}{l}\text { Student } \\
\text { discipline }\end{array}$ & $\begin{array}{l}\text {-Black students, especially males and low-income students, were more likely } \\
\text { to receive certain types of exclusionary consequences such as out-of-school } \\
\text { suspension, expulsion, and referrals to 'Alternative Learning Environments' } \\
\text { relative to in-school suspension }\end{array}$ \\
\hline 4 & $\begin{array}{l}\text { Anttila and } \\
\text { Väänänen } \\
(2015)\end{array}$ & $\begin{array}{l}\text { Pedagogy, } \\
\text { Culture \& } \\
\text { Society }\end{array}$ & $\begin{array}{l}\text { A literature } \\
\text { review }\end{array}$ & $\begin{array}{l}\text { A literature } \\
\text { review }\end{array}$ & Competitiveness & -Emphasised the nature of teaching as a form of emotional labour \\
\hline 5 & $\begin{array}{l}\text { Anyon et } \\
\text { al. (2014) }\end{array}$ & $\begin{array}{l}\text { Children and } \\
\text { Youth } \\
\text { Services } \\
\text { Review }\end{array}$ & ND & $\begin{array}{l}\text { Denver Public } \\
\text { Schools } \\
\text { Administrative } \\
\text { Dataset }\end{array}$ & Punishment & $\begin{array}{l}\text {-Restorative practices in schools have potential as an inclusive strategy to } \\
\text { improve school discipline outcomes without excluding students from the } \\
\text { classroom }\end{array}$ \\
\hline 6 & $\begin{array}{l}\text { Agasisti } \\
\text { and } \\
\text { Longobard } \\
\text { i }(2014)\end{array}$ & $\begin{array}{l}\text { Economics } \\
\text { Bulletin }\end{array}$ & $\begin{array}{l}\text { Prior study of } \\
\text { Jain, Bassey, } \\
\text { Brown, and } \\
\text { Kalra (2014) }\end{array}$ & PISA & Competitiveness & $\begin{array}{l}\text {-The education system in schools can play a role in helping economically } \\
\text { poor students to overcome a disadvantaged family background }\end{array}$ \\
\hline
\end{tabular}




\begin{tabular}{|c|c|c|c|c|c|c|}
\hline 7 & $\begin{array}{l}\text { Anyon et } \\
\text { al. }(2016)\end{array}$ & $\begin{array}{l}\text { American } \\
\text { Journal of } \\
\text { Community } \\
\text { Psychology }\end{array}$ & $\begin{array}{l}\text { Prior study of } \\
\text { Anyon et al. } \\
(2014)\end{array}$ & $\begin{array}{l}\text { Surveys and } \\
\text { administrative } \\
\text { data }\end{array}$ & Punishment & $\begin{array}{l}\text {-Findings discovered that youth from groups that tend to be overrepresented } \\
\text { in suspensions and expulsions (e.g. Black, Latino, and Native American } \\
\text { youth; boys; and students in special education) had similar, if not greater, } \\
\text { rates of participation in restorative interventions than their peers }\end{array}$ \\
\hline 8 & $\begin{array}{l}\text { Arifin } \\
(2015)\end{array}$ & $\begin{array}{l}\text { International } \\
\text { Education } \\
\text { Studies }\end{array}$ & $\begin{array}{l}\text { Gap Theory of } \\
\text { Dessler and } \\
\text { several } \\
\text { Motivational } \\
\text { theories }\end{array}$ & Questionnaire & Competitiveness & $\begin{array}{l}\text { - Organisational culture on output-orientation does not encourage high } \\
\text { working spirits of teachers }\end{array}$ \\
\hline 9 & $\begin{array}{l}\text { Amemiya } \\
\text { et al. } \\
(2020)\end{array}$ & $\begin{array}{l}\text { American } \\
\text { Psychologist }\end{array}$ & $\begin{array}{l}\text { Psychological } \\
\text { Reactance } \\
\text { Theory }\end{array}$ & $\begin{array}{l}\text { Mid-Atlantic } \\
\text { region schools } \\
\text { of the United } \\
\text { States }\end{array}$ & School culture & $\begin{array}{l}\text {-African American adolescents receive more minor infractions than their } \\
\text { white peers }\end{array}$ \\
\hline 10 & $\begin{array}{l}\text { Bartlett et } \\
\text { al. (2017) }\end{array}$ & $\begin{array}{l}\text { International } \\
\text { Journal of } \\
\text { Intercultural } \\
\text { Relations }\end{array}$ & $\begin{array}{l}\text { Acculturation } \\
\text { Theory }\end{array}$ & Interviews & School culture & $\begin{array}{l}\text {-School diversity (extracurricular activities, skill-building activities, } \\
\text { diversified teachers) improved refugee students' growth experience both } \\
\text { academically and socially } \\
\text {-Schools encouraged assimilation to "American culture" while respecting } \\
\text { "home culture" of the refugee students }\end{array}$ \\
\hline 11 & $\begin{array}{l}\text { Baumann } \\
\text { and } \\
\text { Krskova } \\
(2016)\end{array}$ & $\begin{array}{l}\text { International } \\
\text { Journal of } \\
\text { Educational } \\
\text { Management }\end{array}$ & $\begin{array}{l}\text { Human Capital } \\
\text { Theory }\end{array}$ & PISA & $\begin{array}{l}\text { Punishment } \\
\text { Competitiveness } \\
\text { School culture }\end{array}$ & $\begin{array}{l}\text {-The results demonstrate differences in school discipline across five } \\
\text { geographic clusters (Europe, Americas, Far East Asia, rest of Asia, Anglo- } \\
\text { Saxon cluster) with East Asia leading the way } \\
\text {-East Asia ranks first, followed by the rest of Asia for the four discipline } \\
\text { components of students listing well, noise levels, teaching waiting time, and } \\
\text { class start time } \\
\text {-Students who peak perform academically are also the ones with the highest } \\
\text { level of discipline } \\
\text {-School discipline and school uniforms play a vital role in explaining } \\
\text { academic performance }\end{array}$ \\
\hline
\end{tabular}




\begin{tabular}{|c|c|c|c|c|c|c|}
\hline 12 & $\begin{array}{l}\text { Baumann } \\
\text { and } \\
\text { Winzar } \\
(2016)\end{array}$ & $\begin{array}{l}\text { Asia Pacific } \\
\text { Journal of } \\
\text { Education }\end{array}$ & $\begin{array}{l}\text { Hofstede } \\
\text { Cultural } \\
\text { Dimensions }\end{array}$ & $\begin{array}{l}\text { TIMSS, PISA, } \\
\text { interviews }\end{array}$ & $\begin{array}{l}\text { Competitiveness } \\
\text { School culture }\end{array}$ & $\begin{array}{l}\text { - A significant regional difference in education and competitiveness were } \\
\text { identified with East Asia, the rest of Asia, and Anglo-Saxon countries } \\
\text { performing more, and the South/Central American cluster and most European } \\
\text { countries performing less }\end{array}$ \\
\hline 13 & $\begin{array}{l}\text { Baumann } \\
\text { and } \\
\text { Krskova } \\
(2016)\end{array}$ & $\begin{array}{l}\text { Asia Pacific } \\
\text { Business } \\
\text { Review }\end{array}$ & $\begin{array}{l}\text { Institutional } \\
\text { Theory }\end{array}$ & Questionnaire & $\begin{array}{l}\text { Competitiveness } \\
\text { School culture }\end{array}$ & $\begin{array}{l}\text {-Strict discipline and a focus on academic performance contribute more to } \\
\text { work ethic in the Asian countries than Western countries, as these two } \\
\text { components of pedagogy are not significantly linked to work ethic }\end{array}$ \\
\hline 14 & $\begin{array}{l}\text { Baumann } \\
\text { et al. } \\
(2020)\end{array}$ & $\begin{array}{l}\text { Book Name is } \\
\text { Confucianism, } \\
\text { Discipline, and } \\
\text { Competitivene } \\
\text { ss (CDC) }\end{array}$ & $\begin{array}{l}\text { The authors } \\
\text { introduced a } \\
\text { new research } \\
\text { model named } \\
\text { CDC }\end{array}$ & PISA, WEF & $\begin{array}{l}\text { Punishment } \\
\text { Competitiveness } \\
\text { School culture }\end{array}$ & $\begin{array}{l}\text { - A comprehensive investigation of three interrelated concepts: } \\
\text { Confucianism, Discipline, and Competitiveness, and how they relate to } \\
\text { performance in East Asia }\end{array}$ \\
\hline 15 & $\begin{array}{l}\text { Bevington } \\
(2015)\end{array}$ & $\begin{array}{l}\text { Pastoral Care } \\
\text { in Education }\end{array}$ & ND & $\begin{array}{l}\text { Semi- } \\
\text { structured } \\
\text { interviews }\end{array}$ & $\begin{array}{l}\text { Restorative } \\
\text { practices }\end{array}$ & $\begin{array}{l}\text {-Revealed the important factors of congruence (such as climate for learning, } \\
\text { life skills, emotional literacy, behaviour, and relationships) between different } \\
\text { members of the school community }\end{array}$ \\
\hline 16 & $\begin{array}{l}\text { Bottiani et } \\
\text { al. }(2016)\end{array}$ & $\begin{array}{l}\text { Journal of } \\
\text { Youth and } \\
\text { Adolescence }\end{array}$ & $\begin{array}{l}\text { Motivational } \\
\text { development } \\
\text { of engagement } \\
\text { Theory } \\
\text { Skinner and } \\
\text { Pitzer (2012), } \\
\text { Youth } \\
\text { development } \\
\text { and resiliency } \\
\text { models of } \\
\text { Benard (2004) }\end{array}$ & $\begin{array}{l}\text { Maryland } \\
\text { State } \\
\text { Department of } \\
\text { Education }\end{array}$ & $\begin{array}{l}\text { Racial } \\
\text { disparities }\end{array}$ & $\begin{array}{l}\text {-Black students were perceived as less caring and equity relative to white } \\
\text { students overall, and equity and high expectations were lower in diverse } \\
\text { schools for both black and white students } \\
\text {-Identified a need for intervention to improve perceptions of school support } \\
\text { for black youth and for all students in lower income schools }\end{array}$ \\
\hline 17 & $\begin{array}{l}\text { Balfanz } \\
\text { and Fox } \\
(2014)\end{array}$ & $\begin{array}{l}\text { Journal of } \\
\text { Applied } \\
\text { Research on } \\
\text { Children }\end{array}$ & ND & $\begin{array}{l}\text { Florida K-20 } \\
\text { Education } \\
\text { Data }\end{array}$ & School culture & $\begin{array}{l}\text {-Black students were suspended more times than white students } \\
\text {-Special education students were suspended at least once, compared to 9th } \\
\text { grade students without disabilities }\end{array}$ \\
\hline
\end{tabular}




\begin{tabular}{|c|c|c|c|c|c|c|}
\hline & & & & & & $\begin{array}{l}\text {-Free-Reduced Lunch program eligible students were suspended at least once } \\
\text { versus non-eligible students }\end{array}$ \\
\hline 18 & $\begin{array}{l}\text { Belle } \\
(2016)\end{array}$ & $\begin{array}{l}\text { Doctoral } \\
\text { Thesis } \\
\text { University of } \\
\text { South Africa }\end{array}$ & $\begin{array}{l}\text { Socially } \\
\text { Disorganisatio } \\
\mathrm{n} \text { Theory of } \\
\text { Shaw and } \\
\text { Mckay (1969) }\end{array}$ & $\begin{array}{l}\text { Interviews, } \\
\text { observations }\end{array}$ & School culture & $\begin{array}{l}\text {-This study developed a student discipline management model that school } \\
\text { principals may adopt to maintain student discipline in secondary schools }\end{array}$ \\
\hline 19 & $\begin{array}{l}\text { Chi, Liu, } \\
\text { Wang, and } \\
\text { Won Han } \\
(2018)\end{array}$ & $\begin{array}{l}\text { International } \\
\text { Journal of } \\
\text { Science } \\
\text { Education }\end{array}$ & ND & PISA & School culture & $\begin{array}{l}\text {-The disciplinary climate, rather than teacher support, could moderate the } \\
\text { association between inquiry-based science activities and student science } \\
\text { achievement for both genders }\end{array}$ \\
\hline 20 & $\begin{array}{l}\text { Caro, } \\
\text { Lenkeit, } \\
\text { and } \\
\text { Kyriakides } \\
(2016)\end{array}$ & $\begin{array}{l}\text { Studies in } \\
\text { Educational } \\
\text { Evaluation }\end{array}$ & ND & PISA & School culture & $\begin{array}{l}\text {-A positive relationship was found between cognitive activation strategies } \\
\text { (such as more time to think, asking questions, etc.) and mathematics } \\
\text { performance among students }\end{array}$ \\
\hline 21 & $\begin{array}{l}\text { Cheema } \\
\text { and } \\
\text { Kitsantas } \\
(2014)\end{array}$ & $\begin{array}{l}\text { International } \\
\text { Journal of } \\
\text { Science and } \\
\text { Mathematics } \\
\text { Education }\end{array}$ & ND & PISA & School culture & $\begin{array}{l}\text {-An increase in a student's perception of disciplinary climate may lead to a } \\
\text { corresponding increase in math achievement for all three races (white, black, } \\
\text { and Hispanic) }\end{array}$ \\
\hline 22 & $\begin{array}{l}\text { Cornell } \\
\text { and } \\
\text { Bradshaw } \\
(2015)\end{array}$ & $\begin{array}{l}\text { School } \\
\text { Psychology } \\
\text { Review }\end{array}$ & $\begin{array}{l}\text { A literature } \\
\text { review }\end{array}$ & $\begin{array}{l}\text { A literature } \\
\text { review }\end{array}$ & $\begin{array}{l}\text { Racial } \\
\text { disparities }\end{array}$ & $\begin{array}{l}\text {-This article reviewed the literature that emphasised the importance of } \\
\text { bullying prevention in secondary schools }\end{array}$ \\
\hline 23 & $\begin{array}{l}\text { Childs et } \\
\text { al. (2016) }\end{array}$ & $\begin{array}{l}\text { Journal of } \\
\text { Positive } \\
\text { Behaviour } \\
\text { Interventions }\end{array}$ & ND & $\begin{array}{l}\text { Florida } \\
\text { Department of } \\
\text { Education }\end{array}$ & School culture & $\begin{array}{l}\text {-There is a decreasing trend in the frequency of student discipline outcomes } \\
\text { across time for schools implementing SWPBIS } \\
\text {-The schools implementing SWPBIS had a higher academic performance } \\
\text { than schools not implementing SWPBIS }\end{array}$ \\
\hline 24 & $\begin{array}{l}\text { Fergus } \\
(2019)\end{array}$ & $\begin{array}{l}\text { Phi Delta } \\
\text { Kappan }\end{array}$ & $\begin{array}{l}\text { A literature } \\
\text { review }\end{array}$ & $\begin{array}{l}\text { A literature } \\
\text { review }\end{array}$ & $\begin{array}{l}\text { Restorative } \\
\text { practices }\end{array}$ & $\begin{array}{l}\text {-This article reviewed the literature to show how poverty may influence } \\
\text { children's education and discipline levels }\end{array}$ \\
\hline
\end{tabular}




\begin{tabular}{|c|c|c|c|c|c|c|}
\hline 25 & $\begin{array}{l}\text { Greflund et } \\
\text { al. (2014) }\end{array}$ & $\begin{array}{l}\text { Canadian } \\
\text { Journal of } \\
\text { School } \\
\text { Psychology }\end{array}$ & ND & $\begin{array}{l}\text { Archival } \\
\text { records of } \\
\text { Alberta and } \\
\text { British } \\
\text { Columbia }\end{array}$ & School culture & $\begin{array}{l}\text {-Schools implementing Positive Behavioural Interventions and Supports } \\
\text { (PBIS) for students had higher school disciplinary levels }\end{array}$ \\
\hline 26 & $\begin{array}{l}\text { Gregory et } \\
\text { al. (2016) }\end{array}$ & $\begin{array}{l}\text { Journal of } \\
\text { Educational } \\
\text { Psychological } \\
\text { Consultation }\end{array}$ & $\begin{array}{l}\text { Theory on } \\
\text { authoritative } \\
\text { approaches to } \\
\text { adolescents }\end{array}$ & Surveys & $\begin{array}{l}\text { Restorative } \\
\text { practices }\end{array}$ & $\begin{array}{l}\text {-High RP-implementing teachers have more positive relationships with } \\
\text { students and reduced racial discipline issues }\end{array}$ \\
\hline 27 & $\begin{array}{l}\text { Gershoff } \\
(2016)\end{array}$ & $\begin{array}{l}\text { Psychology, } \\
\text { Health, \& } \\
\text { Medicine }\end{array}$ & $\begin{array}{l}\text { A literature } \\
\text { review }\end{array}$ & $\begin{array}{l}\text { A literature } \\
\text { review }\end{array}$ & $\begin{array}{l}\text { Punishment } \\
\text { Competitiveness }\end{array}$ & $\begin{array}{l}\text {-School corporal punishment is consistently linked with harm to children's } \\
\text { learning, physical safety, and mental health, and it is not effective at } \\
\text { maintaining discipline and facilitating academic achievement }\end{array}$ \\
\hline 28 & $\begin{array}{l}\text { Guo et al. } \\
\text { (2018) }\end{array}$ & $\begin{array}{l}\text { Asia Pacific } \\
\text { Education } \\
\text { Review }\end{array}$ & $\begin{array}{l}\text { Situation } \\
\text { Strength } \\
\text { Theory } \\
\text { Mischel } \\
\text { (1976), } \\
\text { Dispersion } \\
\text { Theory Brown } \\
\text { and Kozlowski } \\
\text { (1999) }\end{array}$ & PISA & School culture & $\begin{array}{l}\text {-A significantly positive relationship between climate strength and student } \\
\text { reading performance in China and the United States }\end{array}$ \\
\hline 29 & $\begin{array}{l}\text { Horton } \\
(2015)\end{array}$ & $\begin{array}{l}\text { British Journal } \\
\text { of Sociology } \\
\text { of Education }\end{array}$ & ND & $\begin{array}{l}\text { Observation, } \\
\text { interviews }\end{array}$ & School culture & $\begin{array}{l}\text {-The note passing behaviour was identified as a gendered disciplinary } \\
\text { technique that provides girls to adjust to a more disciplined behaviour than } \\
\text { boys }\end{array}$ \\
\hline 30 & $\begin{array}{l}\text { Hanushek } \\
\text { et al. } \\
\text { (2014) }\end{array}$ & $\begin{array}{l}\text { CESifo } \\
\text { Conference } \\
\text { Paper }\end{array}$ & ND & PIAAC & School culture & $\begin{array}{l}\text {-Teacher skills and student performance are strongly positively associated } \\
\text { across countries, even after extensively controlling for student and family } \\
\text { background, school inputs, institutional features of education systems, and } \\
\text { country-level factors }\end{array}$ \\
\hline
\end{tabular}




\begin{tabular}{|c|c|c|c|c|c|c|}
\hline 31 & $\begin{array}{l}\text { Jerrim, } \\
\text { Oliver, and } \\
\text { Sims } \\
(2020)\end{array}$ & $\begin{array}{l}\text { Learning and } \\
\text { instruction }\end{array}$ & $\begin{array}{l}\text { Cognitive } \\
\text { Load Theory }\end{array}$ & PISA & School culture & $\begin{array}{l}\text {-The inquiry-based instruction method (asking questions, checking } \\
\text { homework) improved teenagers' performance in science examinations }\end{array}$ \\
\hline 32 & $\begin{array}{l}\text { Krskova } \\
\text { and } \\
\text { Baumann } \\
(2017)\end{array}$ & $\begin{array}{l}\text { International } \\
\text { Journal of } \\
\text { Educational } \\
\text { Management }\end{array}$ & $\begin{array}{l}\text { Growth Model } \\
\text { Technological } \\
\text { Diffusion } \\
\text { Theories, } \\
\text { Endogenous } \\
\text { Growth } \\
\text { Theories, } \\
\text { Neoclassical } \\
\text { Theories of } \\
\text { Growth }\end{array}$ & PISA & $\begin{array}{l}\text { Competitiveness } \\
\text { School culture }\end{array}$ & $\begin{array}{l}\text {-There was a relative importance of school discipline ( } 88 \text { per cent) in } \\
\text { comparison to education investment ( } 12 \text { per cent) on educational performance, } \\
\text { with both variables found to be significantly associated with competitiveness }\end{array}$ \\
\hline 33 & $\begin{array}{l}\text { Krskova } \\
(2015)\end{array}$ & $\begin{array}{l}\text { Maters of } \\
\text { Research } \\
\text { Thesis of } \\
\text { Macquarie } \\
\text { University }\end{array}$ & $\begin{array}{l}\text { Growth Model } \\
\text { Technological } \\
\text { Diffusion } \\
\text { Theories, } \\
\text { Endogenous } \\
\text { Growth } \\
\text { Theories, } \\
\text { Neoclassical } \\
\text { Theories of } \\
\text { Growth }\end{array}$ & PISA, WEF & $\begin{array}{l}\text { Competitiveness } \\
\text { School culture }\end{array}$ & $\begin{array}{l}\text {-Emphasised the importance of school discipline in comparison to education } \\
\text { investment on educational performance, with both variables also found to be } \\
\text { significantly associated with competitiveness }\end{array}$ \\
\hline 34 & $\begin{array}{l}\text { Krskova, } \\
\text { Wood, } \\
\text { Breyer, } \\
\text { and } \\
\text { Baumann } \\
(2020)\end{array}$ & $\begin{array}{l}\text { Book Chapter } \\
\text { of F.I.R.S.T: } \\
\text { Principles of } \\
\text { Discipline for } \\
21 \text { st Century } \\
\text { Skills }\end{array}$ & $\begin{array}{l}\text { Human Capital } \\
\text { Theory }\end{array}$ & $\begin{array}{l}\text { Semi- } \\
\text { structured } \\
\text { interviews }\end{array}$ & School culture & $\begin{array}{l}\text {-This chapter presented five principles of discipline based on an informed } \\
\text { work of the } 2000 \text { winner of the Nobel Prize in Economics, James Heckman }\end{array}$ \\
\hline
\end{tabular}




\begin{tabular}{|c|c|c|c|c|c|c|}
\hline 35 & $\begin{array}{l}\text { Kline } \\
(2016)\end{array}$ & $\begin{array}{l}\text { Multicultural } \\
\text { perspectives }\end{array}$ & $\begin{array}{l}\text { A literature } \\
\text { review }\end{array}$ & $\begin{array}{l}\text { A literature } \\
\text { review }\end{array}$ & $\begin{array}{l}\text { Restorative } \\
\text { practices }\end{array}$ & $\begin{array}{l}\text {-This article reviewed the literature that shows how to use restorative } \\
\text { practices as an alternative to punitive practices, to support a reduction in the } \\
\text { number of referrals and suspensions in schools }\end{array}$ \\
\hline 36 & $\begin{array}{l}\text { Lawa et al. } \\
(2019)\end{array}$ & $\begin{array}{l}\text { Jurnal } \\
\text { Pendidikan } \\
\text { Humaniora }\end{array}$ & $\begin{array}{l}\text { Theory of } \\
\text { Learning } \\
\text { Behaviourism }\end{array}$ & $\begin{array}{l}\text { Observation, } \\
\text { interviews }\end{array}$ & School culture & $\begin{array}{l}\text {-School discipline highly depends on daily school activities such as morning } \\
\text { ceremonies, spiritual activities, and scout activities }\end{array}$ \\
\hline 37 & $\begin{array}{l}\text { Lustick } \\
(2017)\end{array}$ & $\begin{array}{l}\text { Race Ethnicity } \\
\text { and Education }\end{array}$ & $\begin{array}{l}\text { A literature } \\
\text { review }\end{array}$ & $\begin{array}{l}\text { A literature } \\
\text { review }\end{array}$ & School culture & $\begin{array}{l}\text {-This article reviewed the existing literature on positive discipline policy and } \\
\text { practice }\end{array}$ \\
\hline 38 & $\begin{array}{l}\text { Losen } \\
(2014)\end{array}$ & $\begin{array}{l}\text { Book Name is } \\
\text { Closing the } \\
\text { School } \\
\text { Discipline } \\
\text { Gap: Equitable } \\
\text { Remedies for } \\
\text { Excessive } \\
\text { Exclusion }\end{array}$ & ND & $\begin{array}{l}\text { Interviews, } \\
\text { surveys, } \\
\text { National } \\
\text { Centre of } \\
\text { Education } \\
\text { statistics }\end{array}$ & School culture & $\begin{array}{l}\text {-Identified several school policies and practices that lead generations of } \\
\text { African American and Latino youth into the school-to-prison pipeline }\end{array}$ \\
\hline 39 & $\begin{array}{l}\text { Martin and } \\
\text { Smith } \\
(2017)\end{array}$ & $\begin{array}{l}\text { Journal of } \\
\text { Urban } \\
\text { Learning, } \\
\text { Teaching, and } \\
\text { Research }\end{array}$ & $\begin{array}{l}\text { Critical Race } \\
\text { Theory } \\
\text { Crenshaw } \\
\text { (1990) }\end{array}$ & $\begin{array}{l}\text { National } \\
\text { Centre of } \\
\text { Education } \\
\text { statistics }\end{array}$ & $\begin{array}{l}\text { Racial } \\
\text { disparities }\end{array}$ & $\begin{array}{l}\text {-African American girls were at much higher risk of both grade retention and } \\
\text { informal reports of discipline problems from teachers, even after controlling } \\
\text { for family factors, school quality, and teacher quality }\end{array}$ \\
\hline 40 & $\begin{array}{l}\text { Mayworm } \\
\text { et al. } \\
(2016)\end{array}$ & $\begin{array}{l}\text { Journal of } \\
\text { Educational } \\
\text { and } \\
\text { Psychological } \\
\text { Consultation }\end{array}$ & $\begin{array}{l}\text { A literature } \\
\text { review }\end{array}$ & $\begin{array}{l}\text { A literature } \\
\text { review }\end{array}$ & $\begin{array}{l}\text { Restorative } \\
\text { practices }\end{array}$ & $\begin{array}{l}\text { - Developed a model for professional development to build teacher } \\
\text { competency in restorative justice }\end{array}$ \\
\hline
\end{tabular}




\begin{tabular}{|c|c|c|c|c|c|c|}
\hline 41 & $\begin{array}{l}\text { Mansfield } \\
\text { et al. } \\
(2018)\end{array}$ & $\begin{array}{l}\text { Educational } \\
\text { Administration } \\
\text { Quarterly }\end{array}$ & ND & $\begin{array}{l}\text { Interviews, } \\
\text { Virginia } \\
\text { Department of } \\
\text { Education }\end{array}$ & $\begin{array}{l}\text { Restorative } \\
\text { practices }\end{array}$ & -The restorative practices reduce suspension and recidivism among students \\
\hline 42 & $\begin{array}{l}\text { Murphy } \\
(2018)\end{array}$ & $\begin{array}{l}\text { Doctoral } \\
\text { dissertation of } \\
\text { University of } \\
\text { Southern } \\
\text { California }\end{array}$ & $\begin{array}{l}\text { Concerted } \\
\text { cultivation } \\
\text { Theory, } \\
\text { Wolterstoff's } \\
\text { Justice Theory }\end{array}$ & $\begin{array}{l}\text { Interviews, } \\
\text { document } \\
\text { analysis }\end{array}$ & $\begin{array}{l}\text { Restorative } \\
\text { practices }\end{array}$ & $\begin{array}{l}\text {-The author identified institutional support as a major factor affecting the RJ } \\
\text { practices }\end{array}$ \\
\hline 43 & $\begin{array}{l}\text { Njoroge } \\
\text { and } \\
\text { Nyabuto } \\
(2014)\end{array}$ & $\begin{array}{l}\text { Journal of } \\
\text { Educational } \\
\text { and Social } \\
\text { Research }\end{array}$ & $\begin{array}{l}\text { Production } \\
\text { Theory }\end{array}$ & $\begin{array}{l}\text { Questionnaires } \\
\text {, interviews }\end{array}$ & $\begin{array}{l}\text { Student } \\
\text { discipline }\end{array}$ & -Identified several factors affecting student indiscipline \\
\hline 44 & $\begin{array}{l}\text { Ning, } \\
\text { Damme, } \\
\text { Den, Yang, } \\
\text { and Gielen } \\
(2015)\end{array}$ & $\begin{array}{l}\text { School } \\
\text { Effectiveness } \\
\text { and School } \\
\text { Improvement }\end{array}$ & ND & PISA & School culture & $\begin{array}{l}\text { - Classroom disciplinary climate significantly affects the reading performance } \\
\text { among students }\end{array}$ \\
\hline 45 & $\begin{array}{l}\text { Ohlson et } \\
\text { al. }(2016)\end{array}$ & $\begin{array}{l}\text { Journal of } \\
\text { Education and } \\
\text { Learning }\end{array}$ & ND & Surveys & School culture & $\begin{array}{l}\text {-When teacher collaboration increases, student suspensions decrease } \\
\text {-When non-certified teachers within a school increased, the student } \\
\text { suspension percentage increased }\end{array}$ \\
\hline 46 & $\begin{array}{l}\text { Okonofua } \\
\text { and } \\
\text { Eberhardt } \\
(2015)\end{array}$ & $\begin{array}{l}\text { Psychological } \\
\text { science }\end{array}$ & ND & $\begin{array}{l}\text { National data } \\
\text { on suspensions } \\
\text { from schools } \\
\text { (Office for } \\
\text { Civil Rights, } \\
\text { 2012) }\end{array}$ & $\begin{array}{l}\text { Racial } \\
\text { disparities }\end{array}$ & $\begin{array}{l}\text {-The racial disparities in suspension rates are even more stark for students } \\
\text { who have been suspended two (or more) times as opposed to students who } \\
\text { have been suspended a single time }\end{array}$ \\
\hline 47 & $\begin{array}{l}\text { Otara and } \\
\text { Uwanyirigi } \\
\text { ra }(2018)\end{array}$ & $\begin{array}{l}\text { Journal of } \\
\text { Education } \\
\text { Practice }\end{array}$ & $\begin{array}{l}\text { Glasser's } \\
\text { Choice Theory }\end{array}$ & Questionnaires & School culture & $\begin{array}{l}\text {-Preventive strategies, such as involving students in their own discipline } \\
\text { management or physically removing materials that take away the attention of } \\
\text { students, positively enhance discipline }\end{array}$ \\
\hline
\end{tabular}




\begin{tabular}{|c|c|c|c|c|c|c|}
\hline 48 & $\begin{array}{l}\text { Peguero } \\
\text { and Bracy } \\
(2015)\end{array}$ & $\begin{array}{l}\text { Journal of } \\
\text { Research on } \\
\text { Adolescence }\end{array}$ & ND & $\begin{array}{l}\text { Educational } \\
\text { Longitudinal } \\
\text { Study of } 2002\end{array}$ & $\begin{array}{l}\text { Student } \\
\text { discipline }\end{array}$ & $\begin{array}{l}\text {-The strongest factor related to students dropping out of school is the formal } \\
\text { school sanctions }\end{array}$ \\
\hline 49 & $\begin{array}{l}\text { Raffenbeul } \\
(2019)\end{array}$ & $\begin{array}{l}\text { Master of } \\
\text { Science Thesis } \\
\text { of St. Cloud } \\
\text { State } \\
\text { University }\end{array}$ & $\begin{array}{l}\text { Whole-child } \\
\text { and } \\
\text { Community- } \\
\text { School Theory }\end{array}$ & $\begin{array}{l}\text { Questionnaires } \\
\text {, interviews }\end{array}$ & $\begin{array}{l}\text { Restorative } \\
\text { practices }\end{array}$ & $\begin{array}{l}\text {-Restorative practices (such as skill-based procedures that connect the victim, } \\
\text { offender, and community in a way that allows empowerment and ownership) } \\
\text { were identified as a viable alternative to traditional discipline procedures }\end{array}$ \\
\hline 50 & $\begin{array}{l}\text { Sortkær } \\
\text { and } \\
\text { Reimer } \\
(2018)\end{array}$ & $\begin{array}{l}\text { School } \\
\text { Effectiveness } \\
\text { and School } \\
\text { Improvement }\end{array}$ & ND & PISA & School culture & $\begin{array}{l}\text {-A significant association was found between the perceived classroom } \\
\text { disciplinary climate of schools and students' mathematics performance across } \\
\text { countries }\end{array}$ \\
\hline 51 & $\begin{array}{l}\text { Sortkær } \\
\text { and } \\
\text { Reimer } \\
(2016)\end{array}$ & $\begin{array}{l}\text { Working Paper } \\
\text { of Danish } \\
\text { School of } \\
\text { Education, } \\
\text { Aarhus } \\
\text { University }\end{array}$ & ND & PISA & School culture & $\begin{array}{l}\text {-A statistically significant relationship between disciplinary climate and } \\
\text { mathematics test achievement was found in Canada, Denmark, and Norway } \\
\text { among } 15 \text {-year students } \\
\text {-Small class size had a strong relationship between disciplinary climate and } \\
\text { student achievement }\end{array}$ \\
\hline 52 & $\begin{array}{l}\text { Semali and } \\
\text { Vumilia } \\
(2016)\end{array}$ & $\begin{array}{l}\text { World Journal } \\
\text { of Education }\end{array}$ & $\begin{array}{l}\text { Glasser's } \\
\text { Choice Theory }\end{array}$ & $\begin{array}{l}\text { Document } \\
\text { analysis, } \\
\text { observations, } \\
\text { field notes, } \\
\text { interviews }\end{array}$ & $\begin{array}{l}\text { Student } \\
\text { discipline }\end{array}$ & $\begin{array}{l}\text {-Teachers strongly suggested that school discipline improves the academic } \\
\text { performance of the students } \\
\text {-Parents strongly expect teachers to maintain proper school disciplinary } \\
\text { levels }\end{array}$ \\
\hline 53 & $\begin{array}{l}\text { Sandoval } \\
\text { and } \\
\text { Białowolsk } \\
\text { i (2016) }\end{array}$ & $\begin{array}{l}\text { Asia Pacific } \\
\text { Education } \\
\text { Review }\end{array}$ & $\begin{array}{l}\text { Resilience } \\
\text { Theory of } \\
\text { Breda } 2001\end{array}$ & TIMSS & School culture & $\begin{array}{l}\text {-In East Asia, positive student attitude to mathematics, teacher confidence in } \\
\text { student performance, and speaking the test language at home improved } \\
\text { students' maths performance } \\
\text {-In Hong Kong and Japan, no single factor was exclusively associated with } \\
\text { socially disadvantaged students' success academically }\end{array}$ \\
\hline
\end{tabular}




\begin{tabular}{|c|c|c|c|c|c|c|}
\hline & & & & & & $\begin{array}{l}\text {-Academic resilience, student academic expectations, and the amount of time } \\
\text { spent on mathematics homework in Singapore were more strongly associated } \\
\text { with higher probabilities of academic success }\end{array}$ \\
\hline 54 & $\begin{array}{l}\text { Ssenyonga } \\
\text { et al. } \\
\text { (2019) }\end{array}$ & $\begin{array}{l}\text { Child Abuse \& } \\
\text { Neglect }\end{array}$ & ND & $\begin{array}{l}\text { Ministry of } \\
\text { Education and } \\
\text { Sports } \\
\text { Uganda, } 2014\end{array}$ & Punishment & $\begin{array}{l}\text { - Teacher training requires the integration of effective stress management, } \\
\text { nonviolent discipline strategies, and attitude change into the curriculum }\end{array}$ \\
\hline 55 & $\begin{array}{l}\text { Salgong et } \\
\text { al. (2016) }\end{array}$ & $\begin{array}{l}\text { Journal of } \\
\text { Education and } \\
\text { Practice }\end{array}$ & $\begin{array}{l}\text { Theory of } \\
\text { Personality, } \\
\text { Humanistic } \\
\text { Theory } \\
\text { Bandura } \\
\text { (1995) }\end{array}$ & $\begin{array}{l}\text { Questionnaires } \\
\text {, interviews }\end{array}$ & $\begin{array}{l}\text { Student } \\
\text { discipline }\end{array}$ & -Lack of guidance and counselling has contributed to indiscipline cases \\
\hline 56 & $\begin{array}{l}\text { Schiff } \\
(2018)\end{array}$ & $\begin{array}{l}\text { Contemporary } \\
\text { Justice Review }\end{array}$ & $\begin{array}{l}\text { A literature } \\
\text { review }\end{array}$ & $\begin{array}{l}\text { A literature } \\
\text { review }\end{array}$ & School culture & $\begin{array}{l}\text { - The zero tolerance and other exclusionary discipline policies in schools } \\
\text { cause mostly minority youth to enter what is now being called 'the school-to } \\
\text { prison pipeline' }\end{array}$ \\
\hline 57 & $\begin{array}{l}\text { Thompson } \\
(2016)\end{array}$ & $\begin{array}{l}\text { Brigham } \\
\text { Young } \\
\text { University } \\
\text { Education and } \\
\text { Law Journal }\end{array}$ & $\begin{array}{l}\text { Critical Race } \\
\text { Theory, } \\
\text { Restorative } \\
\text { Justice Theory }\end{array}$ & $\begin{array}{l}\text { Florida State } \\
\text { website }\end{array}$ & $\begin{array}{l}\text { Student } \\
\text { discipline }\end{array}$ & $\begin{array}{l}\text { The United States school-centric positive behaviour systems (such as } \\
\text { eliminating discriminatory and punitive practices) reduces school-related } \\
\text { arrests and suspensions }\end{array}$ \\
\hline 58 & $\begin{array}{l}\text { Wandasari } \\
\text { et al. } \\
\text { (2019) }\end{array}$ & $\begin{array}{l}\text { International } \\
\text { Journal of } \\
\text { Scientific and } \\
\text { Technology } \\
\text { Research }\end{array}$ & $\begin{array}{l}\text { Miles and } \\
\text { Hubberman's } \\
\text { Theory } 1994\end{array}$ & Interviews & $\begin{array}{l}\text { Student } \\
\text { discipline }\end{array}$ & $\begin{array}{l}\text {-The School Literacy Movement Policy should be continued in State High } \\
\text { Schools as it improves student discipline }\end{array}$ \\
\hline 59 & $\begin{array}{l}\text { Wang } \\
(2016)\end{array}$ & $\begin{array}{l}\text { Asia Pacific } \\
\text { Journal of } \\
\text { Education }\end{array}$ & ND & $\begin{array}{l}\text { Semi- } \\
\text { structured } \\
\text { interviews, } \\
\text { observations, }\end{array}$ & $\begin{array}{l}\text { Student } \\
\text { discipline }\end{array}$ & $\begin{array}{l}\text {-School leaders demonstrated strong instructional leadership and visionary } \\
\text { stewardship for school development }\end{array}$ \\
\hline
\end{tabular}




\begin{tabular}{|c|c|c|c|c|c|c|}
\hline & & & & $\begin{array}{l}\text { policy } \\
\text { documents }\end{array}$ & & \\
\hline 60 & $\begin{array}{l}\text { Wambua } \\
(2017)\end{array}$ & $\begin{array}{l}\text { Master's } \\
\text { Thesis of } \\
\text { University of } \\
\text { Nairobi, } \\
\text { Kenya }\end{array}$ & $\begin{array}{l}\text { Systems } \\
\text { theory by } \\
\text { Ludwig }\end{array}$ & Questionnaires & $\begin{array}{l}\text { Student } \\
\text { discipline }\end{array}$ & $\begin{array}{l}\text {-The schools with students involved in decision making had a high discipline } \\
\text { level }\end{array}$ \\
\hline
\end{tabular}

Source: Developed by author

Please note the following acronyms in the above Table $1 \mathrm{~A}$

- ND in each section means 'not discussed 'or 'not applicable'

- TIMSS denotes 'Trends in International Mathematics and Science Study' conducted by the International Association for the Evaluation of Educational Achievement

- PIAAC denotes 'Programme for the International Assessment of Adult Competencies'

- PISA denotes 'Programme for International Student Assessment' 
